\title{
ANALISIS PEMAHAMAN KONSEP HIMPUNAN MAHASISWA DITINJAU DARI ASAL SEKOLAH
}

\author{
Sudirman \\ Universitas Wiralodra, sudirman_math@yahoo.co.id
}

\begin{abstract}
ABSTRAK
Penelitian ini bertujuan untuk (1) mengkaji pemahaman konsep mahasiswa dalam mengerjakan materi himpunan; (2) mengkaji hubungan pemahaman konsep dalam mengerjakan materi himpunan jika ditinjau dari asal sekolah mahasiswa. Jenis penelitian yang digunakan yakni kualitatif berjenis studi kasus. Subjek penelitian terdiri dari 6 mahasiswa yang masingmasing 2 berasal dari sekolah swasta (SMK dan SMA), 2 dari SMK Negeri dan 2 dari SMA Negeri yang diambil dari teknik clustering. Instrumen yang dijadikan alat analisis yakni tes dan wawancara. analisis data yang digunakan berdasarkan argument yang dikemukakan oleh Milles and Huberman, yakni: reduksi data, penyajian data dan penyimpulan data. Hasil dalam penelitian ini diperoleh bahwa pemahaman konsep mahasiswa beragam dalam menjawab soal materi himpunan. Dari hasil analisis terhadap subjek 1 (S1) yang berasal dari sekolah swasta terlihat bahwa S1 tidak memahami konsep-konsep himpunan. Untuk subjek 2 (S2) dan subjek 3 (S3) yang berasal dari sekolah negeri, terihat sudah memahami konsep himpunan namun keliru dan tidak teliti dalam menjawab soal materi himpunan. berdasarkan wawancara mendalam dengan S1, S2 dan S3 dapat menunjukkan bahwa ada keterhubungan asal sekolah dengan pemahaman konsep mahasiswa dalam menjawab soal materi himpunan.

Kata Kunci: Pemahaman Konsep, Asal Sekolah, Himpunan.
\end{abstract}

\begin{abstract}
The purpose of this research is (1) analyze student's concept in answering the association test, (2) analyze the concept of understanding relationship to answer the test depends on the student's school origin.The method used in this research is qualitative with case study approach. In clustering sampling technique the subject was used in this research is 6 students, shared in 3 groups. They are 2 students come from public vocational school, 2 students come from public senior high school and 2 students come from private senior high school and vocational school. Data was collected through test and interview. Data analysis used in this research refers to Milles and Huberman in Moellong's book; they are data reduction, data display and conclusion drawing. The result showed that the student's understanding is various enough in answering the set test. Depending on the first subject analysis (S1) who came from private school, he did not understand about the concept of set. The second subject analysis (S2) and the third subject analysis (S3) who came from public school, they had understood. But, they need to be careful and patient to avoid the mistakes. The data which had gained from deeply interview, showed that the subject analysis (S1), (S2) and (S3) were able to indicate the relationship of school origin with the student's concept of understanding within answering the set test.
\end{abstract}

Keywords: Understanding, School origin, Set.

How to Cite: Sudirman. (2016). Analisis Pemahaman Konsep Himpunan Mahasiswa Ditinjau dari Asal Sekolah. Mathline: Jurnal Matematika dan Pendidikan Matematika, Vol.1, No.1, 43-52. 


\section{PENDAHULUAN}

Materi himpunan merupakan konsep penting dalam memecahkanan masalah kehidupan sehari-hari. Selain itu banyak konsep-konsep dalam matematika yang dibangun dari konsep tentang himpunan. Menurut Mishra \& Kumar (2014), "theory are used in developing the algebra of groups, rings, and fields, as well as, in developing a logical basis for calculus, geometry, and topology. These branches of mathematics are all applied extensively in the fields of physics, chemistry, biology, and electrical and computer engineering”. Selain itu menurut Sengupta \& Das (2014) didalam penelitiannya menyimpulkan bahwa konsep-konsep didalam himpunan dapat digunakan dalam teknik informatika yakni dalam optimalisasi sistem klasifikasi di komputer jaringan. Berdasarkan hal itu maka belajar tentang konsep himpunan dapat berguna didalam mempelajari ilmu-ilmu yang lain.

Ada banyak kemampuan di matematika yang harus dimiliki oleh mahasiswa dalam memahami matematika. Salah satu kemampuan yang harus dimiliki oleh mahasiswa yakni kemampuan pemahaman konsep. Untuk mengetahui pemahaman mahasiswa terhadap konsep matematika, menurut NCTM (1989) dapat dilihat dari kemampuan mahasiswa dalam: (1) Mendefinisikan konsep secara verbal dan tulisan; (2) mengidentifikasi dan membuat contoh dan bukan contoh; (3) menggunakan model, diagram dan simbol-simbol untuk merepresentasikan suatu konsep; (4) mengubah suatu bentuk representasi ke bentuk lainnya; (5) mengenal berbagai makna dan interpretasi konsep; (6) mengidentifikasi sifat-sifat suatu konsep dan mengenal syarat yang menentukan suatu konsep; (7) membandingkan dan membedakan konsep-konsep.

Salah satu faktor yang menyebabkan tinggi dan rendahnya pemahaman konsep mahasiswa di dalam memahami materi himpunan yakni asal sekolah. Menurut Nugroho \& Pramukantoro (2012) dalam penelitiannya menyimpulkan bahwa latar belakang sekolah menengah mempengarui motivasi dan prestasi akademik mahasiswa di kampus. Sebelum mengikuti perkuliahan matakuliah himpunan dan logika matematika di universitas sebenarnya mahasiswa telah belajar dasar-dasar himpunan pada saat sekolah baik ditingkat dasar ataupun tingkat menengah. Di program studi pendidikan matematika Universitas Wiralodra Indramayu sendiri, mahasiswa yang mengikuti matakuliah himpunan dan logika matematika sangat beragam jika dilihat dari asal sekolahnya. Ada yang berasal dari Sekolah Menengah Kejuaran (SMK) swasta, Sekolah 
Menengah Kejuaran (SMK) negeri, Sekolah Menengah Atas (SMA) swasta dan Sekolah Menengah Atas (SMA) negeri. Jika dilihat dari lokasi sekolah ada yang terdapat di Desa dan ada juga yang terletak di Kota.

Di perkuliahan himpunan dan logika matematika konsep-konsep himpunan seperti: (1) sejarah himpunan; (2) dasar-dasar teori himpunan; (3) diagram venn; (4) operasi himpunan; (5) sifat-sifat operasi himpunan; (6) pembuktian kalimat himpunan; (7) sejarah relasi dan fungsi, (8) pengertian relasi dan sifatnya, (9) pengertian fungsi dan sifat-sifatnya diajarkan selama 7 (tujuh) pertemuan. Selama 7 (tujuh) pertemuan itu, tentunya secara garis besar konsep tersebut sudah pernah di singgung pada saat sekolah. Daya serap mahasiswa dalam memahami konsep himpunan pun beragam ada yang cepat, sedang dan lamban. Oleh karena itu, bisa saja hal itu disebabkan karena faktor latar belakang sekolah.

Berdasarkan uraian diatas maka fokus penelitian ini yakni bagaimanakah pemahaman konsep mahasiswa yang ditinjau dari asal sekolah dalam mengerjakan soal materi himpunan. Dari fokus penelitian itu dibagi menjadi dua rumusan masalah yakni (1) bagaimanakah kemampuan pemahaman konsep mahasiswa dalam mengerjakan soal materi himpunan; (2) bagaimanakah hubungan pemahaman konsep siswa yang ditinjau dari asal sekolah dalam mengerjakan soal materi himpunan?.

\section{METODE PENELITIAN}

Penelitian ini dikategorikan sebagai penelitian kualitatif, yakni karena penelitian ini akan menggambarkan fenomena tentang kemampuan pemahaman konsep mahasiswa yang akan dianalisis secara logis dan mendalam. Waktu Penelitian Penelitian ini dilaksanakan selama 2 bulan, dimulai pada tanggal 14 september sd. 9 november tahun 2015. Subjek Penelitian Mahasiswa Jurusan Pendidikan Matematika semester 1 kelas A yang berjumlah 26 orang. Dan diambil 6 orang untuk diwawancarai sebagai data pendukung pemahaman konsep mahasiswa, berdasarkan kemampuan mahasiswa dalam menyelesaikan masalah yang diajukan peneliti, masing-masing dari yang menyelesaikan benar, hampir benar, dan salah. Instrument yang digunakan untuk menjaring data dalam penelitian ini berdasarkan masalah yang ada, yaitu untuk mengetahui kemampuan mahasiswa dalam menyelesaikan masalah geometri, sehingga instumen penelitian adalah peneliti sendiri dan peneliti menggunakan instrument tes berbentuk essay 
sebagai instrumen pendukung yang sebelumnya telah divalidasi oleh ahli, diantaranya dari segi bahasa, konstruksi soal, dan media yang digunakan, dimaksudkan agar soal tidak menyimpan penafsiran ganda (ambigu) ketika seseorang membacanya.

Langkah-langkah yang dilakukan ketika proses penelitian ini adalah: (1). persiapan yakni pada langkah ini, peneliti menyiapkan semua perangkat formulir terutama instrumen tes yang akan diisi oleh subjek, rubric untuk melihat hasil tes materi himpunan untuk melihat kemampuan pemahaman konsep mahasiswa dengan indikator dalam penelitian ini yakni (a) Mendefinisikan konsep secara verbal dan tulisan; (b) Mengubah suatu bentuk representasi ke bentuk lainnya; (c) Mengenal berbagai makna dan interpretasi konsep; (d) Mengidentifikasi sifat-sifat suatu konsep dan mengenal syarat yang menentukan suatu konsep; (2). Pelaksanaan Instrumen yang telah divalidasi disebarkan kepada mahasiswa, yang selanjutnya dijawab, setelah dikoreksi oleh peneliti, selanjutnya mengkonsultasikannya dengan mencocokan berdasarkan indikator kemampuan pemahaman konsep yang telah dirumuskan. Pada pelaksanaannya lebih ditekankan pada langkah-langkah pengumpulan data kualitatif, yakni terdiri atas reduksi data, penyajian data, dan penyimpulan data. Penelitian ini merupakan penelitian kualitatif, maka analisis data yang digunakan berdasarkan argument yang dikemukakan oleh Milles \& Huberman (Moleong, 2009), yakni: (1) reduksi data yakni data penelitian setelah melalui pengkodingan, selanjutnya data dipilah-pilah karena ketika pengambilan data mungkin ditemukan data-data yang tidak diperlukan oleh peneliti yang tidak diambil sebagai ukuran jawaban masalah penelitian, sehingga data-data itu perlu disaring dan diklasifikasi berdasarkan kebutuhan penelitian; (2) penyajian data yakni setelah data disaring dan diklasifikasikan, selanjutnya data disajikan dalam bentuk kalimat-kalimat yang logis; (3) penyimpulan yakni pada akhir pengambilan data, kemudian dianalisis dan memberikan penyimpulan terhadap kodingan data.

\section{HASIL DAN PEMBAHASAN}

Instrumen yang digunakan untuk pemilihan subjek penelitian adalah soal pemahaman konsep berbentuk uraian. Hasil tes tersebut dianalisis untuk membuat kategori kelompok atas, menengah, dan bawah. Subjek penelitian dipilih sebanyak 6 peserta didik untuk dilakukan wawancara intensif guna mengetahui penyebab kesalahan peserta didik (subjek penelitian) dalam menyelesaikan soal materi himpunan. Adapun 
keenam subjek penelitian dibagi menjadi tiga katagori berdasarkan asal sekolah yakni kategori pertama berasal dari SMA Swasta (S1), Kategori kedua berasal dari SMK Negeri (S2) dan kategori ketiga berasal dari SMA Negeri (S3).

Indikator pemahaman konsep dalam penelitian ini, yiatu (1) mendefinisikan konsep secara tulisan; (2) mengubah suatu bentuk representasi ke bentuk lainnya; (3) mengenal berbagai makna dan interpretasi konsep; (4) mengidentifikasi sifat-sifat suatu konsep dan mengenal syarat yang menentukan suatu konsep.

Tabel 1. Hasil Rekapitulasi Hasil Tes Materi Himpunan

\begin{tabular}{|c|c|c|c|c|c|c|c|}
\hline \multirow[t]{2}{*}{ No } & \multirow[t]{2}{*}{ Nama } & \multirow[t]{2}{*}{ Asal sekolah } & S o a 1 & \multirow{2}{*}{$\frac{\mathrm{M} \text { a te } \mathrm{r}}{\text { No } 2}$} & \multicolumn{2}{|c|}{ H i mpun a n } & \multirow[t]{2}{*}{ Total } \\
\hline & & & No 1 & & No 3 & No 4 & \\
\hline 1 & M1 & SMA SWASTA & 6 & 8 & 6 & 6 & 26 \\
\hline 2 & M4 & SMK NEGERI & 8 & 14 & 8 & 14 & 46 \\
\hline 3 & M5 & SMA NEGERI & 10 & 15 & 10 & 15 & 50 \\
\hline
\end{tabular}

Secara garis besar jika dilihat dari hasil tes materi himpunan maka diperoleh temuan jika dilihat dari indikator pemahaman konsep, diantaranya seperti pada uraian masingmasing subjek. Dengan soal, jika diketahui $S=\{x \mid 0<x<50, x \in$ Asli $\}, P=$ \{Bilangan genap dari 2 sampai 50 yang habis dibagi 4$\}, Q=$ $\{$ Faktor dari 42$\}, R=\{$ Bilangan prima kurang dari 45$\}$. Tentukan : (a) $\left(P^{C} \cup\right.$ $\left.Q^{C}\right)^{C} \cap\left(R^{C}-P\right)$ dan $(\mathrm{b})\left[((P \oplus Q)-R) \cup\left(P-Q^{C}\right]-P\right.$.

\section{Analisis Pemahaman Konsep S1}

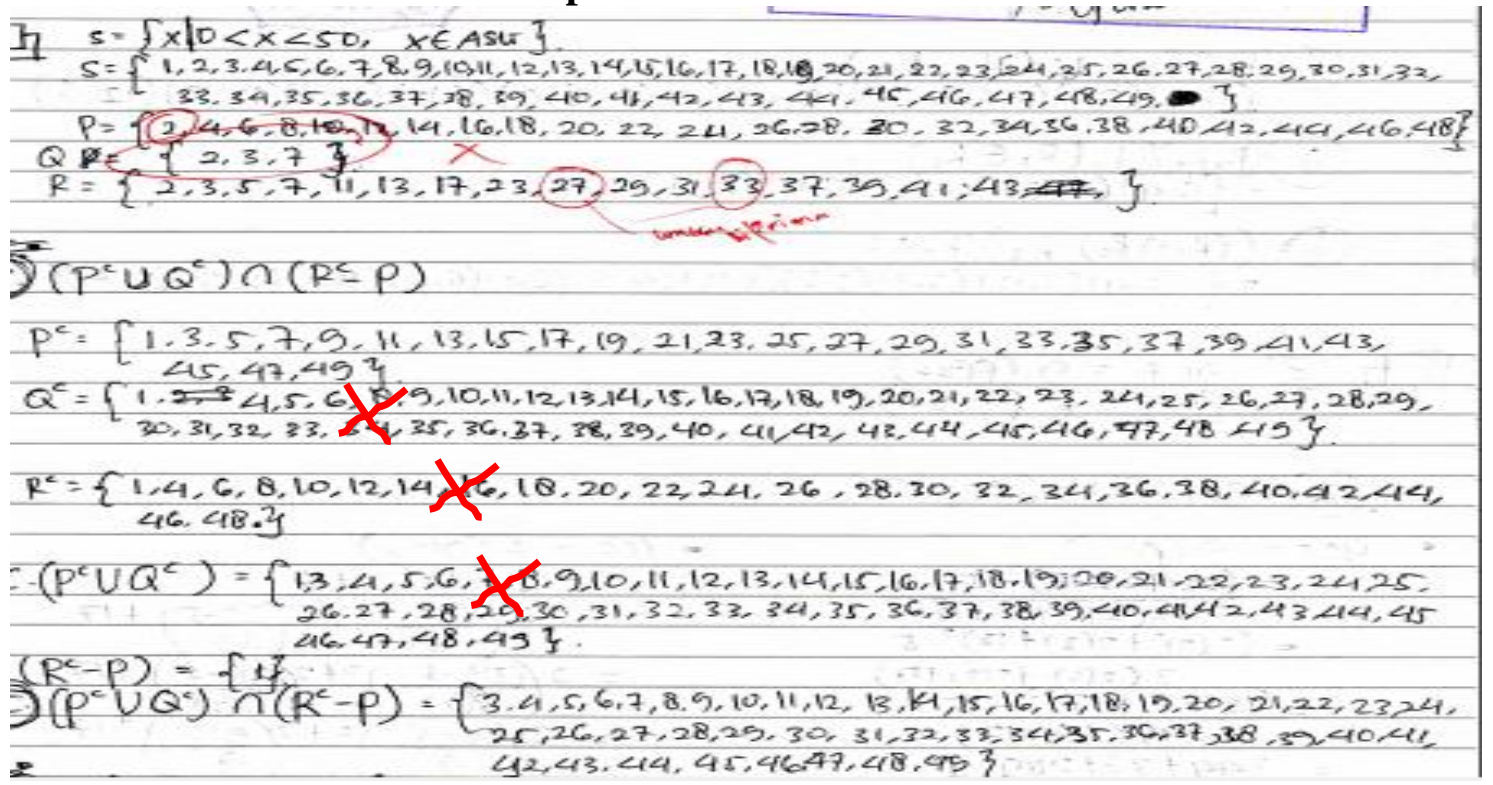

Gambar 1. Hasil Tes S1 
Data hasil tes S1 yang berasal dari sekolah SMA Swasta diperoleh bahwa berdasarkan indikator dari pemahaman kosep secara umum, yakni:

\section{a) Mendefinisikan konsep secara tulisan.}

Jika dilihat dari jawaban terlihat bahwa S1, belum mampu mendefinisikan konsepkonsep untuk menyebutkan anggota-anggota pada himpunan P, Q dan R. Pada himpunan $\mathrm{P}$, untuk menyebutkan anggota pada himpunan $\mathrm{P}$ seharusnya $\mathrm{S} 1$ tidak memunculkan angka 2. Hal itu bisa saja karena ketidaktelitian atau tidak memahami konsep. Untuk menyebutkan anggota himpunan Q juga, S1 salah dalam mendefinisikan konsep tentang faktor dari 42. Hal sama juga terjadi dalam menyebutkan anggota himpunan R, S1 ada sedikit keliru dalam menyebutkan anggota bilangan prima kurang dari 45. Seharusnya S1 tidak memunculkan angka 27, 33, dan 39 yang mengakibatkannya jawabnya kurang tepat.

\section{b) Mengubah suatu bentuk representasi ke bentuk lainnya.}

Pada soal no 1 ketika S1 mampu mereprenstasikan anggota-anggota himpunan P, Q dan R. Hal selanjutnya yakni mengubah ke bentuk lain, pada soal tersebut menentukan komplemen dari himpunan $\mathrm{P}, \mathrm{Q}$ dan R. Karena S1 belum mampu dengan benar menyebutkan anggota-anggota himpunan $\mathrm{P}, \mathrm{Q}$ dan $\mathrm{R}$ sehingga dalam menyebutkan komplemen $\mathrm{P}, \mathrm{Q}$ dan $\mathrm{R}$ juga kurang tepat. Hal itu bisa jadi karena salah konsep atau kurang teliti. Oleh karena itu, perlu penyelidikan dengan wawancara mendalam untuk mengetahui penyebabnya.

c) Mengenal berbagai makna dan interpretasi konsep.

d) Mengidentifikasi sifat-sifat suatu konsep dan mengenal syarat yang menentukan suatu konsep.

Ketika S1 mampu merepresentasikan ke bentuk lainnya maka hal selanjutnya mahasiwa harus mampu memaknai konsep tersebut dan menginterpretasikan ke dalam jawaban pertanyaan yang ditanyakan dalam soal. Apabila jika kita lihat jawaban diatas, maka kita bisa melihat bahwa mahasiswa tidak mampu menjawab dikarenakan konsep awalnya tidak benar. Setelah melakukan analisis konsep terhadap S1, dengan memperhatikan indikator pemahaman konsep dari jawaban hasil tes maka peneliti (P) melanjutkan dengan teknik wawancara. Wawancara dilakukan untuk melihat sejauh mana pemahaman konsep yang dimiliki mahasiswa dan untuk mengetahui sejauh mana hubungan pemahaman konsep siswa dengan asal sekolah. 


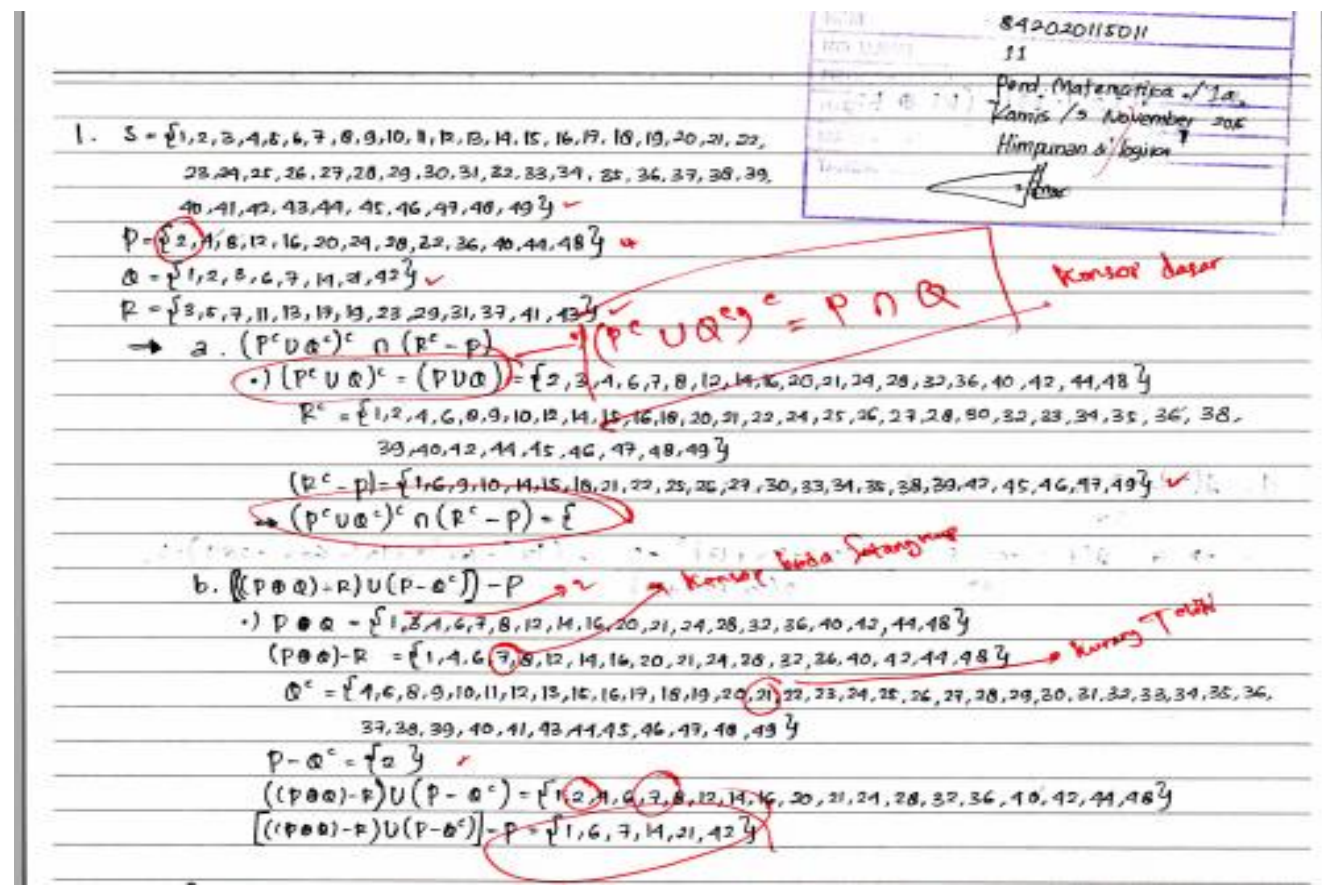

\section{Gambar 2. Hasil Tes S2}

Data hasil tes S1 diperoleh bahwa berdasarkan indikator dari pemahaman kosep secara umum, yakni ;

a) Mendefinisikan konsep secara tulisan.

Jika dilihat dari jawaban terlihat bahwa S2, sudah mampu menentukan anggotaanggota himpunan P, Q dan R. Hanya sedikit kekeliruan dalam menentukan anggota dari himpunan $\mathrm{P}$.

b) Mengubah suatu bentuk representasi ke bentuk lainnya.

Dalam menentukan komplemen dari himpunan P, Q dan R secara konsep sudah benar, tetapi secara konsep dasar himpunan $S 2$ belum mampu mengubah aturan sifat de Morgan. Secara konsep ketika S2 menjawab $\left(P^{C} \cup Q^{C}\right)^{C}=(P \cup Q)$ maka ada kekeliruan dalam menentukan aturan de Morgan. Seharusnya secara konsep $\left(P^{c} \cup\right.$ $\left.Q^{C}\right)^{C} \equiv(P \cap Q)$.

c) Mengenal berbagai makna dan interpretasi konsep.

Dari jawaban S2 terlihat selain konsep aturan de Morgan, ada konsep lain dalam himpunan yang tidak dipahami oleh S2. Akibatnya dalam menginterpretasikan konsep beda setanpup dan konsep operasi himpunan juga S2 salah dalam menjawab soal.

d) Mengidentifikasi sifat-sifat suatu konsep dan mengenal syarat yang menentukan suatu konsep.

Jelas bahwa S2 juga tidak mampu mengidentifikasi sifat-sifat himpunan untuk menjawab soal tersebut, akibatnya hampir seluruh jawaban S2 kurang tepat. Setelah melakukan analisis konsep terhadap S2, selanjutnya dilakukan wawancara. 


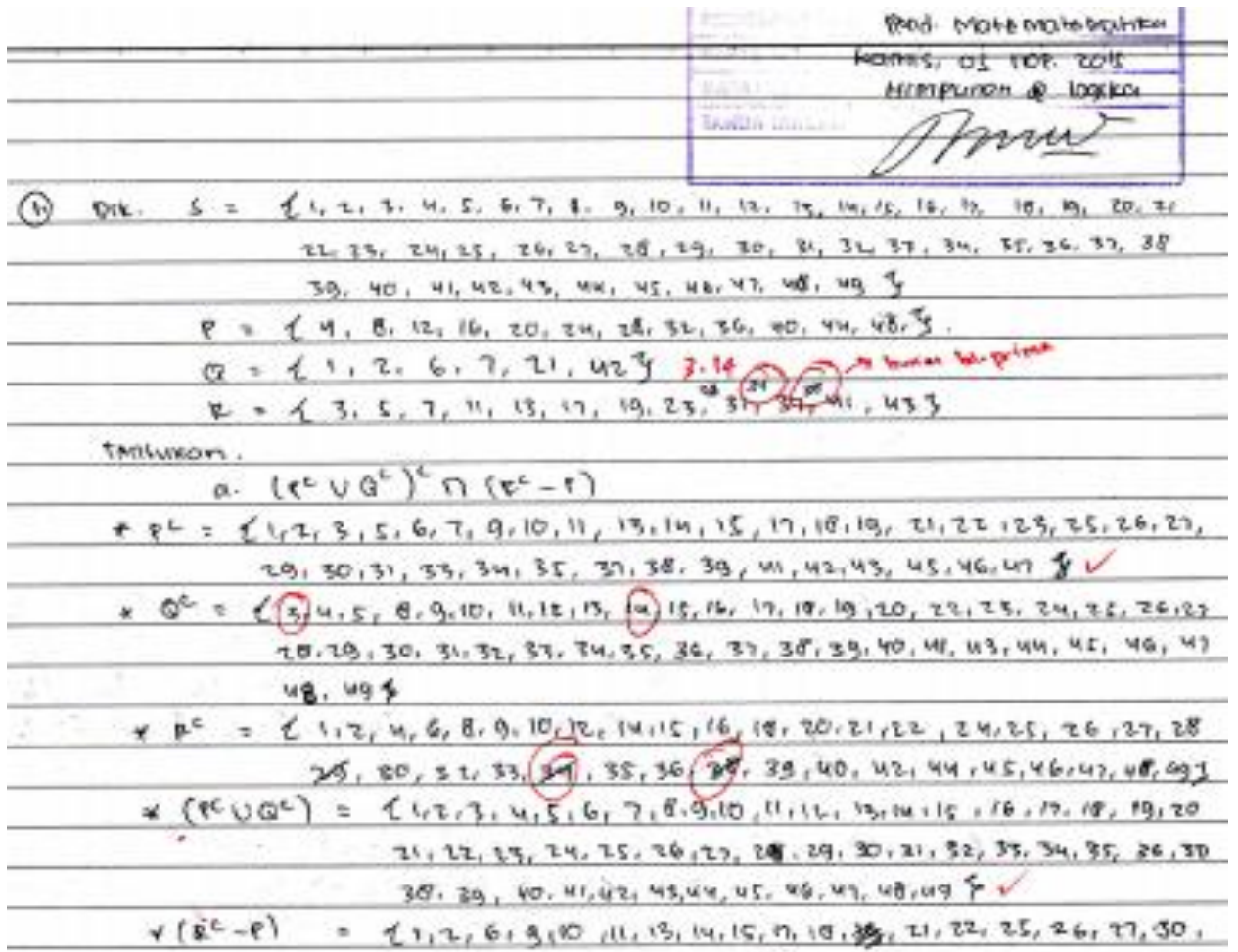

Gambar 3. Hasil Tes S3

Data hasil tes S3 diperoleh bahwa berdasarkan indikator dari pemahaman kosep secara umum, yakni ;

a) Mendefinisikan konsep secara tulisan.

Jika dilihat dari jawaban terlihat bahwa S3 sudah mampu menentukan anggotaanggota himpunan P, Q dan R. Hanya sedikit kekeliruan dalam menentukan anggota dari himpunan Q dan R. S3 tidak memahami konsep faktor dari 42. Akibatnya dia lupa bahwa 3 dan 14 juga merupakan faktor dari 42. Oleh karena itu S3 kurang tepat dalam menentukan anggota-anggota dari himpunan Q. Hal yang sama juga berlaku dalam menentukan anggota dari himpunan R. S3 juga lupa bahwa 21 dan 39 bukan anggota bilangan prima.

b) Mengubah suatu bentuk representasi ke bentuk lainnya.

Secara konsep setelah anggota-anggota himpunan P, Q dan $\mathrm{R}$ sudah ditentukan, maka hal lain yang harus dilakukan S3 yakni mengubah dalam menentukan komplemen P, Q dan R. Dari alur jawaban S3 terlihat secara konsep sudah benar, tetapi karena dalam menentukan anggota-anggota himpunan $Q$ dan Rnya salah maka untuk menentukan komplemen Q dan R juga salah.

c) Mengenal berbagai makna dan interpretasi konsep.

d) Mengidentifikasi sifat-sifat suatu konsep dan mengenal syarat yang menentukan suatu konsep. 
Jelas bahwa S2 juga sebenarnya mampu mengidentifikasi sifat-sifat himpunan untuk menjawab soal tersebut, hanya saja sejak awal dalam menentukan anggota himpuna Q dan R kurang tepat. Akibatnya hampir seluruh jawaban S2 juga kurang tepat. Setelah melakukan analisis konsep terhadap S2, dengan memperhatikan indikator pemahaman konsep dari jawaban hasil tes maka peneliti (P) melanjutkan dengan teknik wawancara. Wawancara dilakukan untuk melihat penyebab kesalahan S3 dalam menjawab soal.

\section{Deskripsi Pemahaman Konsep Mahasiswa dalam Mengerjakan Materi Himpunan}

Berdasarkan indikator pemahaman konsep yang dilakukan S1, S2, dan S3 dalam menyelesaikan soal materi himpunan. Terlihat bahwa ada miskonsepsi dan juga kekeliruan dalam memahami soal yang diberikan. Seperti S1 yang ternyata dia tidak mampu mendifinisikan kosep tentang pertidaksamaan, faktor dari 42 dan bilangan prima dengan benar. Akibatnya S1 salah dalam menentukan anggota-anggota dari himpunan P, Q dan R. Selain itu juga S1 ketika menentukan komplemen dari P, Q dan $\mathrm{R}$ konsep yang digunakan juga kurang tepat. Untuk S2 berdasarkan analisis konsep berdasarkan indikator pemahaman konsep, terlihat S2 sudah mampu mendefiniskan konsep untuk menentukan anggota-anggota dari himpunan P, Q dan R. Hanya saja sedikit kekeliruan dalam menentukan anggota himpunan P. Namun ketika mengubah suatu representasi ke bentuk konsep operasi himpunan dan komplemen, S2 keliru dalam memahami aturan de Morgan dan operasi himpunan. Selanjutnya untuk S3, terlihat sudah mampu menentukan anggota dari himpunan P dan Q. Hanya saja ada sedikit keliru dalam menentukkan anggota dari himpunan R. Ketika mengubah menjadi komplemen dari P, Q dan R secara konsep sudah benar. S2 juga sebenarnya mampu mengidentifikasi sifat-sifat himpunan untuk menjawab soal tersebut, hanya saja sejak awal dalam menentukan anggota himpunan Q dan R kurang tepat. Akibatnya hampir seluruh jawaban S2 juga kurang tepat.

\section{Deskripsi Hubungan Pemahaman Konsep Mahasiswa Ditinjau Dari Asal Sekolah Mahasiswa.}

Jika dilihat dari pemahaman konsep yang dimiliki S1, S2 dan S3 berdasarkan hasil wawancara menunjukkan bahwa sebenarnya mahasiswa sudah pernah mengenal konsep himpunan dari sekolah. Ketika mewancarai S1 yang sekolah di SMA Swasta terlihat S1 ketika di sekolah belum terlalu paham tentang konsep operasi himpunan, pertidaksamaan faktorisasi dan menyebutkan bilangan himpunan. Saat mewancarai S2 yang sekolah di SMK Negeri, sebenarnya S2 juga kurang begitu paham dalam 
menentukan faktor dari 42, dan konsep bilangan prima. Namun dalam memahami konsep operasi himpunan S2 sudah paham, namun ketika menjawab soal S2 kurang teliti dan keliru. Untuk S3 yang sekolah di SMA Negeri juga tidak jauh berbeda dengan S2. S2 sudah memahami konsep dasar dari operasi himpunan dan juga konsep pertidaksamaan, faktor dari 12 dan menentukan bilangan prima. Hanya saja S3 kurang teliti dalam menjawab soal materi himpunan. Sehingga dapat dipahami bahwa terdapat hubungan antara pemahaman konsep dalam menjawab soal materi himpunan dengan asal sekolah. Mahasiswa yang berasal dari SMK atau SMA negeri sudah memahami konsep himpunan hanya saja permasalahannya dalam menjawab soal materi himpunan S1, S2 dan S3 kurang teliti dan keliru.

\section{KESIMPULAN}

Berdasarkan hasil penelitian dan pemabahasan, maka dapat disimpulkan:

1. Pemahaman konsep mahasiswa berdasarkan indikator pemahaman konsep menunjukkan bahwa pemahaman konsep mahasiswa beragam. Dari hasil analisis terhadap S1, S2 dan S3 menunjukkan bahwa hanya S1 yang tidak memahami konsep himpunan. sedangkan untuk S2 dan S3 sudah memahami konsep himpunan, hanya saja ketika menjawab soal materi himpunan mereka keliru dan tidak teliti.

2. Ada hubungan antara pemahaman konsep mahasiswa dalam menjawab materi himpunan ditinjau dari asal sekolah. Dari hasil tes dan wawancara menunjukkan bahwa mahasiswa yang berasal dari sekolah negeri secara pemahaman konsep ketika menjawab materi himpunan lebih baik dibandingkan dengan mahasiswa yang berasal dari sekolah swasta.

\section{DAFTAR PUSTAKA}

NCTM. (1989). Curriculum and Evaluation Standards for School Mathematics. Reston, VA : NCTM.

Moleong, L.(2009). Metodologi penelitian kualitatif. Bandung: PT. Remaja Rosdakarya.

Nugroho, C \& Pramukantoro, J.A. (2012). "Pengaruh Motivasi Belajar Mahasiswa Berdasarkan Latar belakang Sekolah pada Mata KuliahPraktik Dasar Listrik dan Matematika Teknik 1 terhadap Prestasi Belajar Mahasiswa S1 PTE UNESA tahun angkatan 2012". Jurnal Pendidikan Teknik Elektro Volume 03 Nomor 01 Tahun 2014, 97-104.

Mishra, N \& Kumar, V. (2014).“Applications of Set : Why it is necessary”. Internatonal Journal of Innovative Research In Technology, Volume 1 Issue 5 ISSN : 2349-6002.

Sengupta, S \& Kumar, A. (2014). "A Study On Rough Set Theory Based Dynamic Reduct For Classification System Optimization". International Journal of Artificial Intelligence \& Applications (IJAIA), vol. 5, no. 4, july 2014. 